\title{
Effect of operating parameters on performance of ultrafiltration (UF) to fractionate Catfish protein hydrolysate
}

\begin{abstract}
The effect of $\mathrm{pH}$, ionic strength and feed concentration on performance of ultrafiltration (UF) to fractionate Catfish protein hydrolysate $(\mathrm{CFPH})$ through $5 \mathrm{kDa}$ regenerated cellulose $(\mathrm{RC})$ membrane was studied. The highest and lowest permeate flux belonged respectively to $\mathrm{pH} 9$ and isoelectric point (IEP) with flux reduction of $5.75 \mathrm{~L} / \mathrm{m} 2 . \mathrm{h}$ at $\mathrm{pH} 9$ and $10.98 \mathrm{~L} / \mathrm{m} 2 . \mathrm{h}$ at $\mathrm{pH}$ isoelectric through operating time. Further, by adding the salt, the highest permeate flux and transmission obtained at highest ionic strength of $0.15 \mathrm{M} \mathrm{NaCl}$ with $52.96 \%$ of transmission (in average). Then, the transmission reached to $54.18 \%$ by increasing feed concentration up to $1.5 \mathrm{mg} / \mathrm{ml}$.
\end{abstract}

Keyword: $\mathrm{pH}$; Ionic strength and feed concentration; Ultrafiltration (UF); Fish protein hydrolysate 